\title{
Analisis Kebutuhan Pengembangan Bahan Ajar Mata Kuliah Pengantar Profesi Guru Biologi Di Pendidikan Biologi Universitas Ahmad Dahlan Yogyakarta
}

\author{
Analysis Of Needs Development Material Learning Program \\ Introductory Profession Of Biological Teacher In Biology Education \\ Ahmad Dahlan University Yogyakarta
}

\author{
Hani Irawati ${ }^{1}$, Much. Fuad Saifuddin ${ }^{2}$ \\ ${ }^{1}$ Pendidikan Biologi FKIP UAD Yogyakarta \\ *Corresponding author: hani.irawati1986@gmail.com
}

\begin{abstract}
Bahan ajar merupakan salah satu komponen penting yang diperlukan dalam proses pembelajaran. Dengan adanya bahan ajar yang sesuai diharapkan dapat membantu kelancaran kegiatan pembelajaran. Mata kuliah pengantar profesi guru biologi merupakan mata kuliah yang wajib ditempuh oleh mahasiswa semester dua pada program studi pendidikan biologi FKIP UAD. Mata kuliah ini berisi tentang segala hal yang berkaitan dengan profesi seorang guru. Bahan ajar yang selama ini digunakan dalam kegiatan pembelajaran merupakan bahan ajar sederhana yang dibuat oleh dosen dengan mengggunakan referensi berupa aturan perundang-undangan tentang guru. Tujuan penelitian ini adalah untuk mengetahui bahan ajar yang perlu dikembangkan untuk mata kuliah pengantar profesi guru biologi. Subjek penelitian adalah mahasiswa pendidikan biologi angkatan 2016 Universitas Ahmad Dahlan. Sampel dipilih secara acak sebanyak 75 mahasiswa. Data dikumpulkan dengan menggunakan lembar observasi kegiatan perkuliahan dan angket terbuka untuk mahasiswa. Hasil observasi menunjukkan bahwa kendala yang dihadapi pada pembelajaran mata kuliah pengantar profesi guru biologi adalah belum adanya bahan ajar yang bisa dijadikan sebagai pegangan dalam proses pembelajaran. Hasil analisis angket kebutuhan mahasiswa menunjukkan bahwa 1) bahan ajar diperlukan oleh mahasiswa adalah berupa buku ajar, 2) materi di dalam buku ajar berisi tentang: sejarah guru, peraturan tentang guru, kompetensi guru, kompetensi guru biologi, sertifikasi guru, dan profil guru di negara lain. Studi ini merupakan bagian dari studi awal pengembangan buku ajar sebagai bahan ajar mata kuliah pengantar profesi guru biologi.
\end{abstract}

Keywords: $\quad$ analisis, bahan ajar, pengantar profesi guru biologi

\section{PENDAHULUAN}

Bahan ajar merupakan salah satu komponen yang memegang peranan penting dalam proses pembelajaran. Menurut Reza dkk (2016) bahan ajar merupakan salah satu komponen yang dapat membantu kelancaran belajar siswa maupun mahasiswa. Bahan ajar adalah segala bentuk bahan yang digunakan untuk membantu guru/instruktor dalam melaksanakan kegiatan belajar mengajar di kelas (Prastowo, 2012). Bahan yang dimaksud bisa berupa bahan tertulis maupun bahan tidak tertulis. Secara garis besar bahan ajar terdiri atas dua jenis, yaitu bahan ajar cetak dan bahan ajar non cetak. Contoh bahan ajar cetak adalah buku teks, buku ajar, handout, modul, poster, dan leaflet, sedangkan bahan ajar non cetak dapat berupa bahan ajar audio seperti kaset, radio, bahan ajar visual seperti gambar, foto, maupun bahan ajar audiovisual seperti video/film.

Dalam kegiatan pembelajaran bahan ajar memegang peranan yang sangat penting. Bagi pendidik penggunaan bahan ajar yang tepat dapat menghemat waktu dalam mengajar dan dapat mengubah peran pendidik dari seorang pengajar menjadi fasilitator, serta dapat meningkatkan proses pembelajaran menjadi lebih efektif dan interaktif. Bagi peserta didik bahan ajar dapat membantu peserta didik untuk menjadi pembelajar yang mandiri dan dapat digunakan untuk mengukur kompetensi yang telah dikuasai.

Mata kuliah pengantar profesi guru biologi merupakan mata kuliah yang wajib ditempuh oleh mahasiswa program studi pendidikan biologi di Universitas Ahmad Dahlan Yogyakarta dengan bobot 2sks teori. Mata kuliah ini ditempuh oleh mahasiswa semester dua. Mata kuliah pengantar profesi guru 
biologi bertujuan untuk mengenalkan mahasiswa calon guru biologi tentang segala hal yang berkaitan dengan guru pada umumnya dan guru biologi pada khususnya.

Dalam proses pembelajaran yang berlangsung selama ini mahasiswa belum memiliki bahan ajar yang sama yang digunakan sebagai pegangan dalam proses pembelajaran yang dapat mempermudah proses pembelajaran. Mahasiswa memperoleh materi pembelajaran selain dari internet, dari peraturan perundang-undangan dan buku teks. Selain itu, ketergantungan mahasiswa terhadap dosen masih sangat tinggi, terutama kaitannya dengan materi pembelajaran. Dosen masih memegang peranan sebagai sumber belajar utama, sehingga perlu adanya bahan ajar yang dirancang dan dikembangkan oleh dosen untuk mempermudah mahasiswa dalam memahami materi perkuliahan dan untuk menyamakan materi yang dipelajari oleh mahasiswa. Sekaligus bahan ajar tersebut dapat dijadikan sebagai pegangan dalam proses pembelajaran baik oleh dosen maupun oleh mahasiswa.

Tujuan penelitian ini adalah untuk mengetahui bahan ajar yang perlu dikembangkan untuk mata kuliah pengantar profesi guru biologi di pendidikan biologi FKIP UAD sesuai dengan kebutuhan mahasiswa. Hasil dari penelitian ini diharapkan dapat memberikan informasi awal mengenai bahan ajar yang perlu dikembangkan dan materi pembelajaran apa saja yang harus ada di dalam bahan ajar tersebut. Selanjutnya hasil dari penelitian ini digunakan untuk mengembangkan bahan ajar pada penelitian selanjutnya.

\section{METODE PENELITIAN}

Penelitian ini merupakan penelitian deskriptif kualititaif dengan metode survey yang dilaksanakan pada bulan Agustus-September 2017 di program studi

Tabel 1. Hasil observasi pembelajaran mata kuliah pengantar profesi guru biologi pendidikan biologi Universitas Ahmad Dahlan Yogyakarta. Populasi penelitian adalah seluruh mahasiswa semester dua program studi pendidikan biologi Universitas Ahmad Dahlan yang mengambil mata kuliah pengantar profesi guru biologi yang berjumlah 124 mahasiswa. Sampel dipilih secara acak sebanyak 75 mahasiswa.

Teknik pengumpulan data dengan wawancara, observasi dan angket. Instrumen pengumpulan data dengan menggunakan lembar observasi dan angket.. Lembar observasi digunakan untuk memperoleh data tentang kegiatan pembelajaran mata kuliah pengantar profesi guru biologi. Angket terbuka digunakan untuk memperoleh data tentang sumber belajar yang selama ini digunkan oleh mahasiswa, kebutuhan bahan ajar yang diinginkan oleh mahasiwa dan untuk mengetahui materi yang diperlukan oleh mahasiswa. Data hasil penelitian dianalisis secara deskriptif kualitatif.

\section{HASIL DAN PEMBAHASAN}

Hasil

Berdasarkan hasil observasi selama perkuliahan mata kuliah pengantar profesi guru biologi diperoleh data sebagaimana tercantum pada tabel 1. Data hasil angket yang disebarkan kepada mahasiswa terkait sumber belajar yang digunakan oleh mahasiswa ditampilkan dalam tabel 2 Data hasil angket yang disebarkan kepada mahasiswa terkait kebutuhan bahan ajar ditampilkan dalam tabe 3. Data hasil angket terkait materi ajar yang diperlukan oleh mahasiswa calon guru biologi disajikan dalam tabel 4 .

\begin{tabular}{cl}
\hline No & \multicolumn{1}{c}{ Hasil Observasi } \\
\hline 1 & Mahasiswa belum fokus dalam proses pembelajaran karena belum memiliki buku acuan yang digunakan \\
2 & dalam proses pembelajaran \\
3 & Bumber belajar yang digunakan oleh mahasiswa berasal dari internet berupa undang-undang tentang guru \\
4 & Ada mahasiswa yang berbicara sendiri dengan temannya pada saat proses pembelajaran \\
5 & Dosen belum memilki buku pegangan yang dapat dijadikan sebagai bahan ajar dalam proses pembelajaran \\
6 & Dosen masih menjadi sumber belajar utama \\
\hline
\end{tabular}

Tabel 2. Sumber belajar mahasiwa

\begin{tabular}{clc}
\hline No & \multicolumn{1}{c}{ Jenis Sumber Belajar } & Jumlah (\%) \\
\hline 1 & Internet & 63,36 \\
2 & Peraturan perundang- & 33,76 \\
3 & undangan & 14,28 \\
\hline
\end{tabular}

Tabel 3. Kebutuhan bahan ajar mahasiswa

\begin{tabular}{clc}
\hline No & $\begin{array}{c}\text { Jenis bahan ajar yang } \\
\text { diinginkan mahasiswa }\end{array}$ & Jumlah (\%) \\
\hline 1 & Modul & 25,97 \\
2 & Buku Ajar & 41,56 \\
3 & LKM & 22,17 \\
4 & Handout & 10,38 \\
\hline
\end{tabular}


Tabel 4. Materi yang diperlukan mahasiswa

\begin{tabular}{cl}
\hline No & Jenis bahan ajar yang diinginkan mahasiswa \\
\hline 1 & Sejarah guru \\
2 & Peraturan tentang guru \\
3 & Kompetensi guru dan kompetensi guru biologi \\
4 & Sertifikasi guru \\
5 & Profil guru di negara lain \\
\hline
\end{tabular}

\section{PEMBAHASAN}

Berdasarakan observasi yang dilakukan selama perkuliahan pengantar profesi guru biologi, diperoleh informai bahwa belum semua mahasiswa dapat focus dalam kegiatan pembelajaran. Lebih dari $30 \%$ mahasiswa belum mampu berpartisipasi aktif dalam proses pembelajaran, hal ini disebabkan karena belum adanya bahan ajar yang dapat digunakan sebagai pegangan oleh mahasiswa. Belum adanya bahan ajar yang dimiliki oleh mahasiswa menjadikan mahasiswa belum mempersiapkan materi yang akan dipelajari. Karena mahasiswa belum memilki kesiapan sehingga pembelajaran cenderung berjalan satu arah, pada saat diskusi maupun Tanya jawab belum seluruh mahasiswa mampu berpartisipasi.

Sumber belajar yang digunakan oleh mahasiswa dalam perkuliahan selama ini berupa peraturan perundang-undangan, buku teks, maupun artikelartikel yang didownload dari internet. Aturan perundang-undangan terutama tentang guru dan jumlahnya masih sangat terbatas. Adapun artikelartikel yang diambil mahasiswa dari internet keakuratan data dan sumber referensinya belum diketahui kebenarannya. Selain itu, materi yang diperoleh dari buku teks sebagian besar hanya membahas guru secara umum belum adanya pembahasan yang mendalam mengenai guru biologi.

Berdasarkan angket yang dibagikan kepada mahasiswa diperoleh data bahawa mahasiswa menginginkan adanya bahan ajar yang dikembangkan sendiri oleh dosen pengampu mata kuliah dengan menggunakan bahasa yang mudah dipahami oleh mahasiswa, ringkas, dan terdapat soal latihan. Sedangkan jenis bahan ajar yang diinginkan oleh mahasiswa $41.56 \%$ mahasiswa menginginkan adanya buku ajar.

Buku ajar merupakan salah satu jenis bahan ajar yang dapat dijadikan sebagai pegangan bagi mahasiswa dan dosen dalam melaksanakan kegiatan perkuliahan. Buku ajar memiliki karakter yang berbeda dengan buku-buku referensi pada umumnya. Penyusunan buku ajar disesuaikan dengan kurikulum, ditulis dan dirancang berdasarkan kebutuhan peserta didik, menggunakan bahasa yang komunikatif, merujuk kepada kompetensi yang harus dicapai, disusun untuk proses instruksional dan dan memiliki mekanisme umpan balik dari peserta didik. Secara umum dapat dikatakan bahwa buku ajar dapat mengembangkan potensi peserta didik menjadi pembelajar mandiri.
Materi yang diharapkan oleh mahasiswa di dalam buku ajar yang dikembangkan yaitu tentang sejarah guru, peraturan perundangan tentang guru, kompetensi guru, kompetensi guru biologi, sertifikasi guru, dan profil guru di negara lain. Mahasiswa beranggpan bahwa sejarah guru perlu diperkenalkan kepada calon guru agar mahasiswa memahami asal mula profesi guru dan perkembangan profesi guru di Indonesia amupun di luar negeri. Mahasiswa menginginkan materi tentang peraturan perundangundangan tentang guru dengan harapan mampu memahami hak dan kewajiban guru dan hal-hal yang tidak boleh dilakukan oleh guru serta tentang perlindungan hukum bagi guru di Indonesia.

Materi tentang kompetensi guru dan guru biologi yang diharapkan mahasiswa yaitu berisi tentang kompetensi yang harus dikuasai oleh guru secara umum dan kompetensi-kompetensi yang harus dikuasai oleh guru biologi. Secara umum berdasarkan peraturan pemerintah no 74 tahun 2008 seorang guru harus memilki 4 kompetensi, yaitu kompetensi kepribadian, kompetensi social, kompetensi paedagogi, dan kompetensi professional. Guru biologi memiliki kompetensi penciri yang membedakan dengan guru program studi yang lain. Sesuai dengan Permendiknas no 16 tahun 2007 seorang guru mata pelajaran biologi SMA harus memiliki 14 kompetensi khusus. Adapun kompetensi tersebut anatara laian adalah: memahami konsep-konsep, hukum-hukum, dan teori-teori biologi serta penerapannya secara fleksibel, Memahami proses berfikir biologi dalam mempelajari proses dan gejala alam, Menggunakan bahasa simbolik dalam mendeskripsikan proses dan gejala alam/biologi, Memahami struktur ilmu biologi dan ilmu-ilmu lain yang saling terkait, dan yang lainnya.

Materi tentang sertifikasi guru diharapkan dapat memberikan pemahaman kepada mahasiswa tentang fungsi dari sertifikasi dan bagaimana cara memperoleh sertifikat pendidik. Sertifikat pendidik yang diberikan kepada guru atau yang lebih dikenal dengan istilah sertifikasi merupakan sebuah penghargaan profesi yang diberikan oleh pemerintah kepada guru. Dengan adanya sertifikat pendidik untuk guru, maka guru merupakan suatu profesi yang bergengsi dan memiliki hak dan kewajiban yang jelas serta memiliki kesejahteraan yang baik.

Materi mengenai profil guru di Negara lain, diharapkan dapat memberikan gambaran kepada mahasiswa tentang profesi guru tidak hanya di Indonesia tetapi juga di Negara Asia, Eropa, bahkan Amerika. Profil guru pada setiap negara berbeda-beda, begitu juga dengan persyaratan untuk menjadi guru, pendidikan yang harus ditempun untuk menjadi guru, hak dan kewajibannya, tugas-tugasnya bahkan kesejahteraannya.

Pengembangan buku ajar yang akan dilaksanakan merujuk pada prosedur pengembangan model 4-D yang dikemabangkan oleh Thiagarajan (1974) yang terdiri atas Define, Design, Develop, Disseminate. Alasan pemilihan model 4-D didasarkan pada prosedur yang digunakan dalam model ini memberikan kesempatan kepada pembuat buku ajar 
untuk melakukan revisi (evaluasi) secara terusmenerus pada setiap tahap yang dilalui sehingga dapat menghasilkan buku ajar yang lebih baik. Model pengembangan 4-D juga sederhana akan tetapi sistematik dalam mengimplementasikannya.

\section{SIMPULAN}

Berdasarkan data hasil penelitian dan pembahasan yang telah dilakukan dapat disimpulkan bahwa kendala yang dihadapi pada pembelajaran mata kuliah pengantar profesi guru biologi adalah belum adanya bahan ajar yang bisa dijadikan sebagai pegangan dalam proses pembelajaran, bahan ajar yang perlu dikembangkan pada mata kuliah pengantar profesi guru biologi untuk mahasiswa pendidikan biologi FKIP UAD adalah buku ajar. Buku ajar yang dikembangkan berisi materi tentang sejarah guru, peraturan tentang guru, kompetensi guru, kompetensi guru biologi, sertifikasi guru, dan profil guru di negara lain

\section{DAFTAR PUSTAKA}

Ardiansyah, R., Corebima, Rohman, F. (2016). Analisis Kebutuhan Pengembangan bahan Ajar Perubahan Materi Genetik pada Mata Kuliah genetika di Universitas Negeri Malang. Seminar Nasional Pendidikan Saintek 2016.

Pangestuti, A.A., \& Setiawan, D. (2017). Analisis Kebutuhan Buku Ajar Taksonomi Tumbuhan Berbasis Pendekatan Kontruktivisme bagi Mahasiswa Program studi Pendidikan Biologi IKIP Budi Utomo Malang. Seminar Nasional hayati 2017.

Peraturan Pemerintah No.74 tahun 2008. Tentang Guru.

Peraturan Menteri Pendidikan Nasional no 16 tahun 2007. Tentang Standar Kualifikasi Akademik dan Kompetensi Guru.

Prastowo, A. (2012). Panduan Kreatif Membuat Bahan Ajar Inovatif. Yogyakarta: Diva Press.

Thiagarajan, S. (1974). Instructional Development for Training Teachers of Expectional Cgildren. Minneapolis, Minnesota: University of Minnesot. undang-undang no 74 tahun 2008 